dzheno Nakazom MOZ Ukrayiny vid 02.02.2005 No. 54, zareyestrovano v Ministerstvi yustytsiyi Ukrayiny 20.05.2005 r. za No. 552/10832. [Basic sanitary rules of radiation safety of Ukraine (OSSU2005). - Approved by the Order of the Ministry of
Health of Ukraine dated February 2, 2005 No. 54, registered with the Ministry of Justice of Ukraine on May 20, 2005 under No. 552/10832]. zakon2. rada.gov.ua. Retrieved from http://zakon2.rada.gov. ua/laws/show/z0552-05 [in Ukrainian].

\title{
EVALUATION OF TOXICITY OF WATERS FROM THE SURFACE SOURCES OF WATER SUPPLY AND DRINKING WATER OF ZHYTOMYR CITY BY THE METHOD OF SHORT-TERM CHRONIC BIOTESTING
}

\author{
E. Arystarkhova \\ Інститут агроекології і природокористування НААН
}

Обгрунтовано підвищення інформативності тестування вод поверхневих джерел водопостачання та питної води завдяки використанню гладенької шпоркової жаби (Xепориs laevis Daudin, 1802). Як метод досліджень використовували біотестування за тест-реакцією іммобілізації озерної жаби (Rana ridibunda Pallas, 1771) $i$ X. laevis $з$ 8-добовою експозицією особин. Встановлено, що під час біотестування за відсутності іммобілізації $R$. ridibunda не виявлено токсичності дослідних вод, а за іммобілізації $X$. laevis визначено низький рівень водної токсичності у межах 25-50\%. Оиінювання хронічної токсичності вод поверхневих джерел водопостачання та питної води доцільно проводити методом біотестування на X. laevis, які виявились більш чутливими до низьких рівнів забруднень, у середньому на 28,2\% - у гострому досліді тривалістю 4 доби і на 41,3\% - у хронічному досліді тривалістю 8 діб, ніж традиційні тестоб'єкти R. ridibunda.

Ключові слова: біотестування, води джерел водопостачання, питна вода, іммобілізація, $R$. ridibunda, X. laevis, токсичність.

The assessment of water quality in surface water sources and drinking water using physical and chemical analysis does not provide complete information on the complex impact of pollutants on aquatic ecosystems. Therefore, the use of biological methods to determine the toxicity of these waters is particularly relevant [1, 2]. Moreover, the toxicity of drinking water surface waters should be evaluated not only for humans, but also for aquatic organisms [3-8], especially for those which are actively involved in the processes of water quality formation.

Due to the urgent need for monitoring the state of the water from existing methods of biomonitoring, it is expedient to use the

(C) E. Arystarkhova, 2017 biological testing as the obligatory method, which allows, due to high sensitivity, to detect quickly the effects of pollution of surface water sources and drinking water, and at the same time it is much simpler and cheaper in execution, has a time constraint even when determining the chronic toxicity of water and does not require highly qualified labor as physical and chemical methods of research [9-11].

In literature during the last decade much attention has been paid to the feasibility of using sets of several highly sensitive organisms related to different levels of biological organization, through which it is possible to assess the state of the aquatic environment [9-11]. Obligatory representatives of such test kits should be vertebrate animals [10, 
11], including frogs. However, not all species of frog behave equally in the same type of water pollution. In addition, some species are able to react more actively to organic compounds, others - on heavy metals, synthetic surfactants or nanomaterials, etc. $[2,11]$. To identify the creatures that can provide more accurate information on the level of total water toxicity, a prerequisite is to conduct a comparative analysis of a few or more species of frogs, the most sensitive of which are the prospect of being used in biotesting of low contaminated waters.

Taking into account the above mentioned features and the existing literary data on the significant increase in the effectiveness of bioassay for the use of highly sensitive organisms $[10,11]$, we consider that it is necessary to compare two types of unified frogs of marsh (Rana ridibunda Pallas, 1771) and african clawed (Xenopus laevis Daudin, 1802), which are used in international and national standards for determining the toxicity of water $[10,11]$. For the first time, for assessing the toxic effects of water using frogs, the proposed scale of toxicity levels tested on daphnia [4], which is fully consistent with SSanRN (State sanitary rules and norms) 2.2.4-171-10, has been applied.

The goal of the research is to increase the informativeness of the method of testing water from the surface sources of water supply and drinking water using african clawed frog.

\section{MATERIALS AND METHODS OF RESEARCH}

In order to realize the research objective, a comparative analysis of the biotesting of water toxicity was carried out, a sample of which was selected in prepared dishes from the Denyshivske reservoir and Vidsichne water intake of Teteriv river and from the clean water reservoirs (CWR) of CE «ZhytomyrVodokanal» in April 2016 [4]. After sampling the water was poured into aquariums $\left(10 \mathrm{dm}^{3}\right)$ and formed control and test groups according to the following scheme:

- Control group - a test of a settled (24 hours) tap water;
- Test group D-1: water samples - from the Denyshivske reservoir;

- Test group D-2: water samples - from the Vidsichne water intake;

- Test group D-3: water samples - with CWR $5000 \mathrm{~m}^{3}$;

- Test group D-4: water samples - with CWR $20000 \mathrm{~m}^{3}$.

Test-objects: marsh frog ( $R$. ridibunda) and african clawed frog (X. laevis).

Retention: in aquariums, $10 \mathrm{dm}^{3}$ of water, the concentration of oxygen in which is not less than $4 \mathrm{mg} / \mathrm{dm}^{3}$, the temperature $+20^{\circ} \mathrm{C} \pm 2.5^{\circ} \mathrm{C}$, and the density of planting individual $/ 3 \mathrm{dm}^{3}$; in conditions of natural light and replacement of water of appropriate quality every 2 days.

Feeding: animal feed (mosquito larvae, sludge worm).

Test Reaction: immobilization, including mortality of individuals.

Exposure: acute lethal toxicity - for 4 days and short-term chronic toxicity (shortterm chronic toxicity) - within 8 days.

Biotesting: daily calculation of active and immobilized (including dead) individuals from the 1st to the 8th day.

Experiments were carried out in 3-time repeat, using standard techniques and own developments $[4,5,10,11]$.

The obtained data were compared with the control. For each experimental water sample, the toxicity index (\%) for the SSanRN 2.2.4-171-10 [5] was calculated using the following formula:

$$
T=\frac{I_{k}-I_{0}}{I_{k}} 100,
$$

where: $\mathrm{T}-$ index of toxicity, $\%$; $\mathrm{I}_{\mathrm{k}}-$ the value of the test-reaction of individuals in the control; $\mathrm{I}_{\mathrm{O}}$ - the value of the test-reaction of individuals in the experiment.

The water toxicity index should not exceed $50 \%$ regardless the test objects used in the studies.

\section{RESULTS AND DISCUSSION}

One of the most important issues in the context of biotesting of water toxicity is the choice of test objects that must be standardi- 
zed organisms, with which standard experiments have been developed, and which should be adequately responsive to certain levels of pollution of the tested medium. Among the organisms that test biotesting of the aqueous medium the most commonly used are infusoria, daphnia, ceriodaphnia, guppies, common onions, salad dressings, etc. [5-8]. For a long time, these test objects were used to determine the toxicity of natural and sewage, and the development of SSanRN 2.2.4-171-10 contributed to their use in water testing of surface water sources and drinking water [5].

However, for biotesting the quality of these waters, which are much cleaner than other species, traditional organisms were not sufficiently informative. In this regard, the search for unified organisms, by means of which higher efficiency compared with generally accepted test objects, low levels of water pollution can be found.

As test organisms, we tested for sensitivity to toxic components of water 2 species of marsh and african clawed frogs for the test-reaction of immobilization of individu- als, the advantage of which, in comparison with many other frogs reactions, is the simplicity of its determination for the calculation of the number of active and immobilized individuals.

A comparative analysis of the environmental effectiveness of biotesting on marsh frog and african clawed frog of water samples taken in the reservoirs of the Teteriv river and the clean water reservoirs (CWR) at the Communal Enterprise «ZhytomyrVodokanal» is presented in the table:

The obtained data indicate that the test organism proposed for conducting the assessment of the water $X$. laevis by the reaction of immobilization of individuals is more sensitive to the determination of water toxicity than $R$. ridibunda. According to the biotesting data, the scale of the water toxicity levels proposed by us is used, which can be used both for the determination of its acute and chronic toxic effects [4]: 1-25\% - acceptable level of toxicity; $26-50 \%-$ low toxicity; 51-75\% - average toxicity; 76-100\% high toxicity.

\section{Comparative analysis of biotesting with $R$. ridibunda and $X$. laevis of waters from the reservoirs of the Teteriv river and the CWR of Communal enterprise «ZhytomyrVodokanal» $(n=30)$}

\begin{tabular}{|c|c|c|c|c|}
\hline \multirow{2}{*}{ Test groups and figures } & \multicolumn{4}{|c|}{ Toxicity after immobilization of test objects (T, \%): } \\
\hline & R. ridibunda & toxicity level & X. laevis & toxicity level \\
\hline \multicolumn{5}{|c|}{ Acute toxicity } \\
\hline D-1 (Denyshivske Reservoir) & absent & ATL & 35.7 & LTL \\
\hline D-2 (Vidsichne water intake) & absent & ATL & 27.1 & LTL \\
\hline D-3 (CWR 5 000) & absent & ATL & 25.1 & ATL \\
\hline D-4 (CWR 20000$)$ & absent & ATL & 24.9 & ATL \\
\hline Exposure duration, days & 4 & & 4 & \\
\hline \multicolumn{5}{|c|}{ Chronic toxicity } \\
\hline D-1 (Denyshivske Reservoir) & absent & ATL & 49.6 & LTL \\
\hline D-2 (Vidsichne water intake) & absent & ATL & 42.5 & LTL \\
\hline D-3 (CWR 5 000) & absent & ATL & 38.2 & $\mathrm{LTL}$ \\
\hline D-4 (CWR 20000$)$ & absent & ATL & 34.9 & LTL \\
\hline Exposure duration, days & 8 & - & 8 & - \\
\hline
\end{tabular}

Note: $\mathrm{I}_{\mathrm{M}}$ - immobilization of frogs; $\mathrm{T}$ - index of water toxicity (in relation to control); levels of toxicity of water: ATL - admissible, LTL - low. 
African clawed frog is a model for investigation in medical and ecological biotechnology. This species of frog should be sensitive enough to the chronic toxic effects of water components of surface water sources and drinking water. Therefore, it is important to compare the sensitivity to the chronic toxicity of water given by $X$. laevis with such a widespread aquatic toxicology as a species of frog like $R$. ridibunda.

In the experiment, in the test-reaction of immobilization of $R$. ridibunda, only the permissible level of toxicity was detected in all investigated water species. However, it is obvious that water from surface water sources and drinking water can not have the same toxicity. This fact has been proved by us with the use of a more sensitive species of X. laevis. Thus, for the determination of acute and chronic effects of water, not only the permissible levels of their toxicity (ATL) were revealed, which in fact indicate a lack of harmful effects on organisms, but also low levels (LTL) within the toxicity index of $25-50 \%$. The highest value of the toxicity index was detected determining the chronic effect of water in the reservoir of Denyshivske district of Teteriv, somewhat lower - in the water intake of the Attic. The determination of the acute effects of water in these groups also revealed higher levels of toxicity compared with the levels of toxicity of drinking water. Although the $50 \%$ limit on water hazard was not exceeded, biotesting with african clawed frog was on $26.3 \%$ average (in the acute study) and $36.6 \%$ (in the chronic study) more effective than testing on marsh frog.

Consequently, under the same conditions of biotesting with $R$. ridibunda and X. laevis, the latter showed a significantly higher sensitivity to the toxic components of water sources of water supply and drinking water in the conditions of the Communal enterprise «ZhytomyrVodokanal».

\section{CONCLUSIONS}

The evaluation of chronic toxicity of water from surface sources of water supply and drinking water is proposed to be carried out by the method of biotesting with X. laevis, which turned out to be more sensitive to low levels of contamination on average $28.2 \%$ in an acute study of duration 4 days and $41.3 \%$ in the short-term chronic study duration of 8 days than the traditional test-object of $R$. ridibunda.

\section{ЛITЕРАТУРА}

1. River watch. Manual for public environmental monitoring. - SPb.: Friends of the Baltics; Coalition Clean Baltics, 2015. - 32 p.

2. Nanostructured zinc oxide-cotton fibers: synthesis, characterization and applications / I.M. El-Nahhal, S.M. Zourab, F.S. Kodeh et al. // Jornal of Materials Science. - 2013. - P. 3970-3975.

3. Malik A. Environmental Deterioration and Human Health: Natural and anthropogenic determinants / A. Malik, E. Grohmann, R. Akhtar. - Dordrecht, Heidelberg, London, New York: Springer, 2014. $-421 \mathrm{p}$.

4. Аристархова Е.О. Експрес-оцінка потенційної небезпеки води методом біотестування на Daphnia magna S. / Е.О. Аристархова // Вісник аграрної науки. -2017 . - № 2. - С. 50-54.

5. Гігієнічні вимоги до води питної, призначеної для споживання людиною: ДСанПіН 2.2.4-171-10 за № 452/17747 / МОЗ України. - [Чинний від 1.07.2010 р.]. - К., 2010. - 50 с. - (Державні стандарти України).

6. Zooplankton (Cladocera) species turnover and longterm decline of Daphnia in two high mountain lakes in the Austrian Alps / L. Nevalainen, M. Ketola, J.B. Korosi et al. // Hydrobiologia. - 2014. - Vol. 722 (1). - P. 75-91.

7. Water quality. Determination of long term toxicity of substances to Daphnia magna Straus (Cladocera, Crustacea): ISO 10706: 000. - Paris, 2000. - 26 p.

8. Jakob U. Oxidative Stress and Redox Regulation / U. Jakob, D. Reichmann. - Dordrecht, Heidelberg, London, New York: Springer, 2013. - 486 p.

9. Скок С.В. Оцінювання якості питної води м. Херсона методом біотестування / С.В. Скок // Агроекологічний журнал. - 2015. - № 2. - С. 2630.

10. Комплексна оцінка токсичності водних зразків за допомогою рослинних і тваринних тест-організмів / М.С. Осмалений, А.М. Головков, А.В. Нанієва, М.Р. Верголяс // Фактори експериментальної еволюції організмів. - 2015. - Т. 16. - С. 74-77.

11. Пат. 10804 А Україна, МПК G 01 N 33/18; G 01 N 21/76. Спосіб комплексного визначення генетичної безпечності питної води / В.В. Гончарук; заявник та патентовласник В.В. Гончарук; заявл. 5.11.2015, опубл. 11.04.2016, Бюл. № 7. 


\section{REFERENCES}

1. River watch. Manual for public environmental monitoring. (2015). SPb.: Friends of the Baltics; Coalition Clean Baltics [in English].

2. El-Nahhal, I.M., Zourab, S.M., Kodeh, F.S. (2013). Nanostructured zinc oxide-cotton fibers:synthesis, characterization, and applications. Jornal of Materials Science, 3970-3975 [in English].

3. Malik, A., Grohmann, E., Akhtar, R. (2014). Environmental Deterioration and Human Health: Natural and anthropogenic determinants. Dordrecht Heidelberg, London, New York: Springer [in English].

4. Arystarkhova, E.O. (2017). Ekspress-otsinka potentsiinoi nebespeky vody metodom biotestuvannia na Daphnia magna S. [Express-estimatiom of potential danger of water by the biotesting method with Daphnia magna S.]. Visnyk agrarnoi nauky - Bulletin of Agrarian Science, 2, 50-54 [in English].

5. Higiyenichni vymogy do vody pytnoi, prysnachenoi dlya spo vzhyvannya ludynoiu [Hygiene requirements to drinking water intended for human consumption"]. DSanPiN 2.2.4-171-10, No. 452/17747 from $1^{\text {ht }}$ July 2010. Kyiv: Ministerstvo okhorony sdorovia Ukrainy [in Ukrainian].

6. Nevalainen, L., Ketola, M., Korosi, J.B. (2014). Zooplankton (Cladocera) species turnover and longterm decline of Daphnia in two high mountain lakes in the Austrian Alps. Hydrobiologia, 722, 1, 75-91 [in English].
7. Water quality. Determination of long term toxicity of substances to Daphnia magna Straus (Cladocera, Crustacea) BS 6068-5. 28:2000, ISO 10706: 2000 [in English].

8. Jakob, U., Reichmann, D. (2013). Oxidative Stress and Redox Regulation. Dordrecht, Heidelberg, London, New York: Springer [in English].

9. Skok, S.V. (2015). Otsiniuvannia yakosti pytnoi vody $\mathrm{m}$. Khersona metodom biotestuvannia [Evaluation potable water quality Kherson sity by the method biological testing]. Ahroekolohichnyi zhurnal - Agroecological jornal, 2, 26-30 [in Ukrainian].

10. Osmalenyi, M.S., Holovkov, A.M., Nanijeva, A.V., Vergolias, M.R. (2015). Compleksna otsinka toksychnosti vodnykh srazkiv za dopomogoju roslynnykh I tvarynnykh test-orhanizmiv [Comprehensive evalution of toxicity of water samples using plant and animal test-organisms]. Faktory eksperymentalnoi evolutsii orhanismiv - Factors of organisms experimental evolution, 16, 74-77 [in Ukrainian].

11. Honcharuk, V.V. (2016). Sposib kompleksnogo vyznachennia henetychnoi bezpechnosti pytnoi vody [Metod of comprehensive determination of drinking water genetical safety]. Ukranian patent No. 10804, MPK G 01 N 33/18; G 01 N 21/76. 11.04.2016, Bul. 7 [in Ukrainian]. 